\title{
ANALISIS LIKUIDITAS DAN PROFITABILITAS PT. BANK PERKREDITAN RAKYAT LENGAYANG
}

\author{
Suci Rahmadani, Yosep Eka Putra \\ Akademi Keuangan dan Perbankan"Pembangunan" Padang \\ rmdsuci03@gmail.com
}

\begin{abstract}
The purpose of this study is to determine how the ratio of liquidity and profitability at PT.Bank Perkreditan Lengayang. The research method used is qualitative and quantitative data analysis methods. Qualitative methods are methods that explain the data under study during the study. while the quantitative method is to analyze the development of a bank's financial statements. and the type of data used, namely secondary data obtained from reports of financial services authorities, as well as rural bank publication reports for 2016-2020. To measure the soundness level of a bank, two ratios are used, namely the liquidity ratio (in the form of $C R, Q R$ and $L D R$ ) and the ratio of profitability (in the form of ROA, ROE, BOPO and NPM). The results of this study indicate that the level of the bank's liquidity ratio is in a healthy position because the bank is able to pay back its short-term obligations. The company's profitability ratio from 2016-2020 shows a value that fluctuates every year, but is still in a healthy position.
\end{abstract}

Keywords : Liquidity,Profitability.

\section{PENDAHULUAN}

Keadaan ekonomi suatu negara dipengaruhi oleh banyak faktor, diantaranya yaitu di bidang perbankan memiliki fungsi pokok sebagai lembaga penghimpunan dana masyarakat. Menurut Undang-undang RI No. 10 Tahun 1998 tentang perbankan, menurut jenisnya bank dibagi menjadi dua yakni bank umum dan bank perkreditan rakyat.

Keberadaan BPR di Indonesia mampu menunjukkan peranannya dalam memberikan jasa kepada usaha kecil dan menengah, karena BPR diarahkan untuk melayani usaha kecil dari masyarakat di perdesaan dan juga untuk memenuhi kebutuhan masyarakat dalam bidang keuangan dengan ketentuan yang lebih mudah dibandingkan dengan bank umum. Supaya dapat menjalankan tugas pokok dan mempertahankan kelangsungan BPR, kepercayaan masyarakat sangat penting dan memperoleh gambaran tentang perkembangan keuangan suatu bank, perlu mengadakan analisis terhadap data keuangan dari bank yang bersangkutan dimana data tersebut dapat dilihat dalam laporan keuangan.

Menurut Tanor, Dkk (2015) Laporan keuangan adalah hasil proses akuntansi yang dipakai sebagai alat mengkomunikasikan data keuangan kepada pihak yang berkepentingan. Laporan keuangan yang dikenal yaitu Neraca, Laporan Laba Rugi atau Hasil Usaha, Laporan Perubahan Modal, Laporan Arus Kas, serta Laporan Posisi Keuangan (Ottay \& Alexander, 2015). 
Analisis rasio adalah cara yang digunakan dalam menganalisis laporan keuangan perusahaan. Salah satu analisis rasio yang digunakan adalah rasio likuiditas dan profitabilitas.

Tujuan dari laporan keuangan bank yaitu untuk memberikan informasi tentang posisi keuangan, kinerja suatu perusahaan, perubahan ekuitas atau modal, arus kas, dan informasi penting lainnya yang bermanfaat bagi pengguna laporan keuangan. Dengan hadirnya BPR di tengah masyarakat dapat meningkatkan pertumbuhan ekonomi masyarakat bagi usaha kecil dan menengah.

PT. Bank Perkreditan Rakyat Lengayang adalah salah satu BPR yang ada di Pesisir Selatan. BPR ini perlu memperhatikan tingkat likuiditas dan profitabilitas dalam melunasi utang jangka pendek serta kemampuan perusahaan dalam memperoleh keuntungan yang dimiliki oleh bank. Berikut data keuangan yang digunakan untuk mengetahui perkembangan likuiditas, dan profitabilitas PT. BPR Lengayang.

\section{Tabel 1}

Likuiditas dan Profitabilitas

Tahun 2016- 2020

\begin{tabular}{|c|c|c|c|c|c|c|}
\hline Keterangan & 2016 & 2017 & 2018 & 2019 & 2020 & $\begin{array}{l}\text { Standar } \\
\text { Rata-rata }\end{array}$ \\
\hline $\mathrm{CR}$ & $23,40 \%$ & $30,33 \%$ & $21,64 \%$ & $22,38 \%$ & $29,14 \%$ & $>=4,05 \%$ \\
\hline QR & $670,21 \%$ & $130,65 \%$ & $179,64 \%$ & $141,35 \%$ & $121,82 \%$ & $>18 \%$ \\
\hline LDR & $88,46 \%$ & $80,27 \%$ & $91,82 \%$ & $90,76 \%$ & $82,63 \%$ & $<=94,75 \%$ \\
\hline ROA & $3,05 \%$ & $3,04 \%$ & $3,00 \%$ & $2,61 \%$ & $1,61 \%$ & $\geq 1,22 \%$ \\
\hline ROE & $24,07 \%$ & $20,95 \%$ & $21,14 \%$ & $19,18 \%$ & $13,83 \%$ & $\geq 18 \%$ \\
\hline BOPO & $78,85 \%$ & $76,23 \%$ & $77,57 \%$ & $84,97 \%$ & $89,14 \%$ & $<90 \%$ \\
\hline NPM & $17,84 \%$ & $19,77 \%$ & $19,03 \%$ & $12,38 \%$ & $9,29 \%$ & $>5 \%$ \\
\hline
\end{tabular}

Sumber : Data Diolah

\section{Grafik}

Likuiditas dan Profitabilitas

Tahun 2016-2020

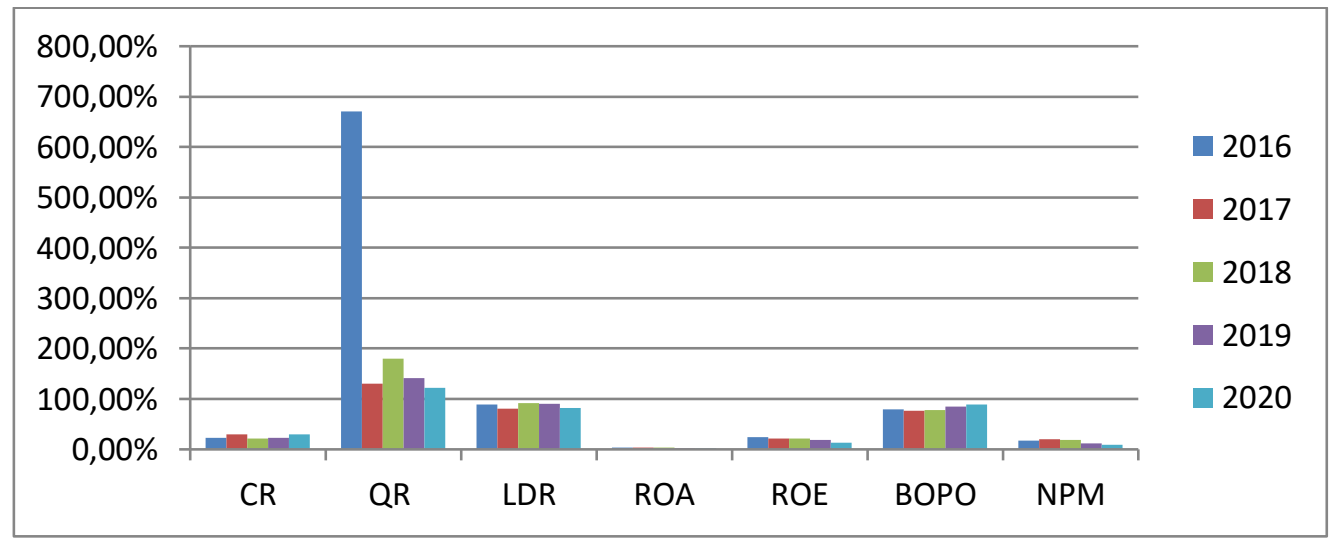

Sumber : Data Diolah 
Berdasarkan tabel 1 Dapat diketahui bahwa perkembangan likuiditas dan profitabilitas PT. Bank Perkreditan Rakyat Lengayang dapat dikatakan sehat karena sesuai dengan ketentuan Bank Indonesia. Dilihat dari perkembangan rasio likuiditas PT. BPR Lengayang pada setiap periodenya berada pada posisi sehat karena bank tersebut mampu memenuhi kewajiban jangka pendeknya saat jatuh tempo. Untuk perkembangan rasio profitabilitas PT. BPR Lengayang pada setiap periode berada pada posisi sehat karena bank tersebut mampu memperoleh keuntungan dari pihak DPK.

\section{LANDASAN TEORI \\ Pengertian Bank}

Bank yaitu badan usaha yang kegiatan utamanya yaitu mengembangkan dana dari masyarakat dalam bentuk simpanan, kemudian memberikannya kembali untuk memperoleh keuntunga nserta menyediakan jasa-jasa dalam lalu lintas pembayaran di dalam suatu perusahaan tersebut (Nopiana and Chasanah 2017).

\section{Pengertian BPR}

Dalam undang-undang perbankan pasal 1 ayat 2 No. 10 tahun 1998 perubahan dari undang-undang No. 7 tahun 1992 dinyatakan bahwa BPR ialah bank melakukan kegiataan usaha secara konvensional atau berdasarkan prinsip Syariah dalam kegiatannya tidak memberikan jasa dalam lalu lintas pembayaran.

\section{Pengertian Laporan Keuangan}

Laporan keuangan ialah hasil akhir dari proses akuntansi yang menyediakan informasi berguna untuk pengambilan keputusan oleh berbagai pihak (Tanor, Dkk, 2015). Bank memiliki beberapa jenis laporan keuangan yang sesuai dengan Standar Akuntansi Keuangan (SAK) antara lain ;
a. Neraca
b. Laporan komitmen dan kontijensi
c. Laporan laba rugi
d. Laporan arus ka
e. Catatan atas laporan keuangan

\section{Pengertian Likuiditas dan Profitabilitas}

Likuiditas adalah kemampuan bank untuk melunasi kewajiban finansial jangka pendek tepat waktunya yang ditunjukkan oleh besar kecilnya aktiva lancer (Menurut Putri \& Marlius, 2018).

Rasio profitabilitas adalah rasio yang menggambarkan kakuatan perusahaan untuk menghasilkan keuntungan dari pengguna modal.

\section{METODE PENELITIAN}

Untuk keperluan penelitian ini, pengumpulan data dilakukan dengan 2 cara yaitu:

\section{Metode Pengumpulan Data}

a. Riset Perpustakaan (Library Research)

Yaitu penelitian ini dilakukan dengan cara mempelajari buku-buku, makalahmakalah, artikel-artikel, bacaan laporan-laporan dan publikasi yang berhubungan dengan objek penelitian.

b. Riset Lapangan (Field Research)

Adalah melakukan penelitian langsung untuk menghasilkan data primer dan sekunder. 


\section{Metode Analisa Data}

Metode penelitian yang digunakan yaitu metode analisis data kualitatif dan kuantitatif. Dimana metode kualitatif menggambarkan, memahami dan menjelaskan data yang diteliti selama penelitian berlangsung. Sedangkan metode kuantitatif menganalisa perhitungan likuiditas dan profitabilitas PT. BPR Lengayang.

\section{HASIL DAN PEMBAHASAN}

Berdasarkan data keuangan PT. Bank Perkreditan Rakyat Lengayang yang diperoleh, selanjutnya dilakukan perhitungan rasio keuangan dengan 2 macam yaitu likuiditas dan profitabilitas, masing-masing terdiri dari 3 indikator untuk likuiditas dan 4 indikator untuk profitabilitas sebagai berikut :

\section{Rasio Likuiditas}

Menurut (Munawir 2004;31 2019) pengertian likuiditas ialah menggambarkan kemampuan perusahaan untuk memenuhi segala kewajiban finansial yang harus segera dipenuhi untuk memenuhi kewajiban.

a. Cash Ratio (CR)

Merupakan rasio alat likuid terhadap dana pihak ketiga yang dihimpun bank dan harus dibayar.

Kriteria penilaian Cash Ratio menurut SK DIR BI Nomor : 30/12/KEP/DIR tanggal 30 april 1997 tentang cara penilaian tingkat kesehatan BPR sebagai berikut :

Keterangan Kriteria

Sehat

$$
>=4,5 \%
$$

Cukup sehat

$$
>=3,30 \%-<=4,05 \%
$$

Kurang sehat

$>=2,55 \%-<3,30 \%$

Tidak sehat

$<2,55 \%$

Sumber : (SK Direksi Bank Indonesia Nomor 30/12/KEP/DIR tanggal 30 April 1997).

Cash Ratio $=\frac{\text { alat likuid }}{\text { hutang lancar }} \times 100 \%$

b. Quick Ratio (QR)

Quick ratio menurut Faizal (2014) merupakan rasio yang menggambarkan kemampuan aktiva lancar bank yang paling likuid mampu menutupi hutang lancarnya. Quick Ratio menurut SK Direksi Bank Indonesia Nomor 30/12/KEP/DIR tanggal 30 April 1997 tentang tata cara penilaian tingkat kesehatan BPR sebagai berikut :

\begin{tabular}{ll}
\hline Keterangan & Kriteria \\
\hline Sehat & 81 \\
Cukup sehat & $66 \mathrm{~s} / \mathrm{d}<81$ \\
Kurang sehat & $51 \mathrm{~s} / \mathrm{d}<66$ \\
Tidak sehat & $0 \mathrm{~s} / \mathrm{d}<51$ \\
\hline
\end{tabular}

Sumber : (SK Direksi Bank Indonesia Nomor 30/12/KEP/DIR tanggal 30 April 1997 2013). 
Quick Ratio $=\frac{\text { kas }}{\text { kewajiban segera }} \times 100 \%$

c. LDR

Loan to Deposit Ratio yaitu kebijakan bank dalam melunasi kembali dana penarikan yang telah dilakukan oleh deposan dengan menggunakan kredit yang diberikan bank dengan dana yang diterima oleh bank.

Kriteria penilaian Cash Ratio menurut SK DIR BI Nomor : 30/12/KEP/DIR tanggal 30 April 1997 tentang tata cara penilaian tingkat kesehatan BPR (Taufik, 2012).

\begin{tabular}{ll}
\hline Keterangan & Kriteria \\
\hline Sehat & $<=94,75 \%$ \\
Cukup sehat & $>94,75 \%-<=98,50 \%$ \\
Kurang sehat & $>98,50 \%-<102,25 \%$ \\
Tidak sehat & $>102,25 \%$
\end{tabular}

Sumber : (SK DIR BI Nomor : 30/12/KEP/DIR tanggal 30 April 1997).

\section{Rasio Profitabilitas}

$$
\mathrm{LDR}=\frac{\text { Total loans }}{\text { total deposit }} \times 100 \%
$$

Menurut (Yanti \& Afriyeni, 2017) untuk melihat kemampuan bank dalam memperoleh laba pada periode tertentu maka digunakan rasio profitabilitas.. Rasio profitabilitas menggunakan beberapa rasio keuangan seperti, Return on Asset (ROA), Return on Equity (ROE), Biaya Operasional (BOPO), dan Net Profit Margin (NPM).

\section{a. ROA}

Menurut ( Afriyeni \& Fernos, 2018) ROA adalah alat untuk mengetahui tingkat keuntungan yang dihasilkan perusahaan dengan memanfaatkan semua aset yang dimilikinya. Sesuai SK Direksi BI No. 30/12/KEP/DIR tanggal 30 April 1997 tentang penilaian tingkat kesehatan Bank Perkreditan Rakyat pada tingkat ROA yaitu dengan score minimal $1,22 \%$ dikatakan baik.

b. ROE

$$
\mathrm{ROA}=\frac{\text { laba sebelum pajak }}{\text { total aktiva }} 100 \%
$$

ROE menunjukkan dari modal sendiri untuk memperoleh keuntungan bagi pemegang saham preferen dan saham biasa, semakin besar rasio ini maka akan semakin baik. Bahwa Return on Equity merupakan rasio yang mengukur kemampuan suatu paerusahaan dalam memperoleh laba bersih dari modal sendiri yang digunakan oleh perusahaan. Menurut standar BI ROE adalah lebih dari 12\% (baik).

c. BOPO

$$
\mathrm{ROE}=\frac{\text { laba setelah } \text { pajak }}{\text { modal sendiri }} \times 100 \%
$$

Rasio BOPO digunakan untuk mengukur perbandingan antara biaya operasional yang ditanggung bank apabila dibandingkan dengan pendapatan operasional yang mampu dihasilkan. Menurut standar BI menetapkan rasio BOPO yaitu dibawah 90\%, jika rasio BOPO melebihi 
90\% hingga mendekati $100 \%$ maka bank tersebut dapat dikategorikan tidak efisien dalam menjalankan kegiatan operasionalnya.

d. NPM

$$
\mathrm{BOPO}=\frac{\text { total beban operasional }}{\text { total pendapatan operasional }} \times 100 \%
$$

Net Profit Margin (NPM) adalah rasio yang menghitung sejauh mana kemampuan perusahaan memperoleh laba pada tingkat penjualan tertentu. Semakin tinggi berarti menunjukkan kemampuan perusahaan memperoleh laba yang tinggi pada tingkat penjualan tertentu. Menurut standar BI NPM lebih dari 5\% (baik).

$$
\mathrm{NPM}=\frac{\text { laba bersih setelah pajak }}{\text { total pendapatan operasional }} \times 100 \%
$$

\section{SIMPULAN}

Berdasarkan penilaian kinerja keuangan pada PT. BPR Lengayang dari tahun 2016 sampai 2020 terhadap laporan keuangan nya melalui analisis rasio keuangan yaitu rasio likuiditas dan profitabilitas maka dapat disimpulkan sebagai berikut : Rasio Likuiditas perusahaan dari tahun 2016 sampai 2020 menunjukkan bahwa Cash Ratio (CR) PT. Bank Perkreditan Rakyat Lengayang pada tahun 2016- 2020 berada pada posisi sehat, karena berada diatas standart yang telah ditentukan oleh BI. Hal ini menunjukkan bahwa bank mampu dalam membayar kembali simpanan nasabahnya jika nasabah tersebut melakukan penarikan terhadap uangnya yang tersimpan di bank.Pada Quick Ratio (QR), PT. Bank Perkreditan Rakyat Lengayang tahun 2016-2020 berada dalam posisi sehat atau dapat dikatakan bank mampu dalam membayar kewajiban jangka pendeknya menggunakan aktiva lancar yaitu kas yang dimiliki bank tersebut. Pada Loan To Deposit Ratio (LDR), PT. Bank Perkreditan Rakyat Lengayang pada tahun 20162020 dapat dikatakan sehat, karena LDR berada pada posisi $<=94,75 \%$. Dan pada setiap tahunnya bank selalu mengalami perubahan yang semakin membaik, sehingga bank berada pada posisi sehat.

Rasio profitabilitas perusahaan dari tahun 2016 sampai 2020 menunjukkan nilai yang naik turun setiap tahunnya, tetapi masih dalam standar BI. Rasio ROA PT. BPR Lengayang Pada Tahun 2016 nilai ROA sebesar 3,05\%, tahun 2017 nilai ROA sebesar 3,04, tahun 2018 nilai ROA sebesar 3,00\%, tahun 2019 nilai ROA sebesar 2,61\%, tahun 2020 nilai ROA sebesar $1,61 \%$. Pada tahun 2019-2020 mengalami penurunan, meskipun demikian kinerja PT. BPR Lengayang tetap baik karena nilainya masih diatas rata-rata penilaian BI. Apabila ROA semakin rendah bank tidak akan bisa beroperasi dengan efektif dan efisien dalam memanfaatkan asset yang dimilikinya dalam memperoleh keuntungan. Rasio ROE PT. Bank Perkreditan Rakyat Lengayang pada tahun 2016 nilai ROE sebesar 24,07\%, tahun 2017 nilai ROE sebesar 20,95\%, tahun 2018 nilai ROE sebesar $21,14 \%$, tahun 2019 nilai ROE sebesar 19,18\% dan pada tahun 2020 nilai ROE sebesar 13,83\%. Mengalami penurunan, sehingga kemampuan bank dalam memperoleh laba bersih dari modalnya rendah. Rasio BOPO PT. BPR Lengayang pada tahun 2016 nilai BOPO sebesar 78,85\%, tahun 2017 
nilai BOPO sebesar 76,23\%, tahun 2018 nilai BOPO sebesar 77,57\%, tahun 2019 nilai BOPO sebesar 84,97\%, dan pada tahun nilai BOPO sebesar $89,41 \%$. Semakin kecil BOPO semakin efisien bank tersebut mengendalikan biaya operasionalnya, maka laba yang diperoleh bank akan semakin besar. Rasio NPM PT. BPRLengayang pada tahun 2016 nilai NPM sebesar 17,84\%, tahun 2017 nilai NPM sebesar 19,77\%, tahun 2018 nila NPM sebesar 19,03\%, tahun 2019 nilai NPM sebesar 9,29\%, dan pada tahun 2020 nilai NPM sebesar 9,29\%. Semakin besar NPM semakin efisien bank tersebut mengendalikan biaya operasionalnya, maka keuntungan yang diperoleh bank akan semakin besar.

\section{UCAPAN TERIMA KASIH}

Terima kasih penulis sampaikan kepada : Bapak Mohd. Fatsi Tanjung, SH selaku pimpinan PT. Bank Perkreditan Rakyat Lengayang yang telah mengizinkan penulis dalam memperoleh informasi beserta pengambilan data.

\section{DAFTAR PUSTAKA}

Cintia, I., \& Marlius, D. (2021). Analisis Laporan Keuangan Berdasarkan Rasio Likuiditas Pada PT. Bank Perkreditan Rakyat Batang Kapas. https://doi.org/10.31219/osf.io/be3vr

Lendriani, L. \& Marlius, D. (2021). Analisis Rasio Likuiditas Pada PT. Bank Pembangunan Daerah Sumatera Barat. https://doi.org/10.31219/osf.io/ep2wn

Marlius, D., \& Pebriyana, S. (2020). Analisis Rasio Profitabilitas Pada Pt. Bank Pembangunan Daerah Sumatera Barat Cabang Utama Padang. https://doi.org/10.31219/osf.io/7gnd5

Marlius, D., \& Mutia, M. (2020). Analisis Rasio Profitabilitas Pada Pt. Bank Pembangunan Daerah Sumatera Barat Cabang Pembantu Rsup Dr. M. Djamil Padang. https://doi.org/10.31219/osf.io/9nrc7

Marlius, D., \& Ilhami, S. (2020). Analisis Ratio Profitabilitas Pada Pt. Bank Perkreditan Rakyat Jorong Kampung Tangah Pariaman. https://doi.org/10.31219/osf.io/f9gau

Ottay, M. C., \& Alexander, S. W. (2015). Analisis Laporan Keuangan Untuk Menilai Kinerja Keuangan pada PT. BPR Citra Dumoga Manado. Jurnal Emba, 3(1), 923-932.

Putri, D. M., \& Marlius, D. (2020). Analisis Rasio Profitabilitas Pada Pt. Bank Perkreditan Rakyat Lugas Dana Mandiri Padang. https://doi.org/10.31219/osf.io/kaw2e

Rahmayeli, D. S., \& Marlius, D. (2018). Analisis Kinerja Keuangan Pada Pt. Bank Perkreditan Rakyat (Bpr) Batang Kapas Pesisir Selatan. 1-7. https://doi.org/10.31227/osf.io/sz5db

Rani Astuti, Y. E. P. (n.d.). Analisis Likuiditas dan Solvabilitas Pada PT. Bank Perkreditan Rakyat Jorong Kampung Tangah Pariaman. 1-11.

Sundari, E., \& Marlius, D. (2021). Analisis Rasio Profitabilitas PT. Bank Perkreditan Rakyat Batang Kapas. https://doi.org/10.31219/osf.io/szh52 
Syawia, A. A., \& Marlius, D. (2021). Analisis Rasio Profitabilitas PT. Bank Perkreditan Rakyat Lengayang Cabang Surantih. https://doi.org/10.31219/osf.io/c9k3r

Tanor, M. O., \& Dkk. (2015). Analisis Laporan Keuangan Dalam Mengukur Kinerja Keuangan Pada PT. Bank Artha Graha Internasional, Tbk Financial. Jurnal Emba, 3(3), 639-649

Vernida, M., \& Marlius, D. (2020). Analisis Rasio Profitabilitas Pada Pt. Bank Perkreditan Rakyat Cempaka Mitra Nagari Padang. https://doi.org/10.31219/osf.io/6usfx 